Brazilian Journal

of Chemical

Engineering

\title{
SEQUENTIAL PROCESSING OF Psidium guajava L. LEAVES: STEAM DISTILLATION AND SUPERCRITICAL FLUID EXTRACTION
}

\author{
Caroline G. F. da Silva ${ }^{1}$, Aline M. Lucas ${ }^{1}$, Alexandre T. do E. Santo ${ }^{1}$, \\ Rafael N. Almeida ${ }^{1}$, Eduardo Cassel ${ }^{1}$ and Rubem M. F. Vargas ${ }^{1 *}$ \\ ${ }^{1}$ Pontifícia Universidade Católica do Rio Grande do Sul, Faculdade de Engenharia, Porto Alegre, RS, Brasil. \\ E-mail: caroline.finkler@acad.pucrs.br; aline.lucas@pucrs.br; alexandre.santo@acad.pucrs.br; rnolibos@gmail.com; cassel@pucrs.br; \\ rvargas@pucrs.br, ORCID: 0000-0003-2696-8581
}

(Submitted: April 24, 2017 ; Revised: January 18, 2018 ; Accepted: January 28, 2018)

\begin{abstract}
Extracts from the leaves of Psidium guajava L have been studied due to their importance as a source of natural antioxidant components with possible applications in the pharmaceutical and food industries. In this work, the sequential use of steam distillation and supercritical fluid extraction was studied to obtain the essential oil from the leaves and non-volatile compounds from the residue. The non-volatile compounds were obtained by $\mathrm{CO}_{2}$ supercritical extraction. Experiments were performed in a automated pilot-scale extractor at constant pressure of $15 \mathrm{MPa}$, at $313 \mathrm{~K}$ and $333 \mathrm{~K}$ in three different flow rate conditions. The analysis of the essential oil with GC-MS identified E-caryophyllene, $\beta$-selinene1, $\alpha$-selinene, selin-11-en-4- $\alpha$-ol and E-nerolidol as main compounds. Antioxidant activity was observed in all extracts. The experimental extraction curves were compared to simulated ones predicted by a mathematical model based on mass transfer principles with two adjustable parameters. The model used fitted accurately the experimental data.

Keywords: Supercritical fluid extraction; Psidium guajava L.; Essential oil; Antioxidant compounds.
\end{abstract}

\section{INTRODUCTION}

The guava tree (Psidium guajava L.) is a small tree native to Central and South America. Its leaves are opposite, short-petiolate, the blade oval with prominent pinnate veins, $5-15 \mathrm{~cm}$ long (Gutiérrez et al., 2008). The plant is included in the Brazilian National Report of Medicinal Plants of Interest to the Public Health System (RENISUS, 2014). The leaves are a source of $P$. guajava essential oil that is used in Brazilian folk medicine for numerous illnesses (Soliman et al., 2016).

The search for new medicinal plant based products is a very active field of research (Jayathilake et al., 2016). It is also known that the intake of plant-derived foods and beverages on a regular basis reduces the risk of coronary heart disease, stroke and cardiovascular diseases, improving antioxidant defense mechanisms as well as presenting more efficient immune responses (Corti et al., 2009; Aslani and Ghobadi, 2016).There are numerous reports of antioxidant activity in extracts from the aerial parts of the P. guajava tree (CastroVargas et al., 2010; Nantitanon et al., 2010; Fernandes et al., 2014; Laily et al., 2015). This activity is often attributed to the presence of phenolic compounds such as quercetin, catechin and gallic acid (Diaz-de-Cerio et al., 2016). The nutritional and health-promoting (e.g., anti-plasmodial, anti-inflammatory, hepatoprotective and anticancer) properties of $P$. guajava indicate the potential nutraceutical use of this plant(Lee et al., 2012; Flores et al., 2015)

Different methods (e.g., hydrodistillation, solvent extraction) can be used to separate volatile compounds in the form of essential oils from plant materials. Steam distillation is a traditional method extensively used not

\footnotetext{
* Corresponding author: Rubem M. F. Vargas - E-mail: rvargas@pucrs.br
} 
only in research but also in industry for the obtainment of essential oils (Xavier et al., 2011).

Supercritical fluid extraction is a technique widely used in separation processes of natural products, providing some operational advantages that overcome many limitations of conventional extraction methods(de Azevedo et al., 2008; Sovová and Stateva, 2011). Bed porosity, solvent flow, temperature, pressure, and particle size (Barroso et al., 2011) are the main factors that influence the extraction process and can be easily adjusted. Another advantage, compared to other extraction techniques, is the use of solvents generally recognized as safe (GRAS), carbon dioxide being the solvent more often selected. Fluids in supercritical state present high diffusivity, low viscosity, and low surface tension. Such properties are desirable in solvent sused for extraction of components from solid matrices.

Mathematical models that effectively describe and predict the extraction kinetics of steam distillation of volatile oils and supercritical extraction from plants are an inevitable step for the design and scale-up from laboratory to pilot and industrial scale(del Valle and de La Fuente, 2006). Models used to describe the experimental process of supercritical extraction are frequently based on differential mass balances for the fluid and solid phases, like those proposed by Reverchon (1996) and Sovová (1994; 2005).Models based on principles of desorption and mass transfer are also often used for steam distillation data (Cerpa et al., 2008; Cassel et al., 2010).

The main objective of this work was to study the sequential extraction of $P$. guajava leaves. Initially, the leaves were steam distilled to remove the essential oil from the plant material. Afterwards, the residue was dried and extracted with supercritical $\mathrm{CO}_{2}$ to obtain extracts rich in phenolic compounds. This approach secures the recovery of a larger range of compounds of interest and minimizes the waste of plant material. The results for extraction yields, composition of essential oil, phenolic content of the extracts, and their antioxidant potential were assayed. The mass transfer aspect was evaluated using a mathematical model.

\section{MATERIAL AND METHODS}

\section{Plant Material}

The plant was collected in winter, before flowering season in Porto Alegre in the state of Rio Grande do Sul, southern Brazil. Twigs were separated anddiscarded; only the green leaves were selected for further experiments.

\section{Steam Distillation}

Before the supercritical fluid extraction, the essential oil was extracted from the green leaves through steam distillation. The procedure basically consists in the passage of steam generated in a boiler through the bed where the plant material was placed. The solute was carried over in the steam and then condensed by contact with a cold fluid. The separation of essential oil and water occurs naturally due the difference of density between the phases. The volume of oil extracted was monitored at intervals of 5 minutes throughout the extraction until it stabilized, thus indicating the end of the operation. The experiments were carried out with $0.4 \mathrm{~kg}$ of leaveswith average thickness of $2.4 \times 10^{-4} \mathrm{~m}$ and solid density of $690 \mathrm{~kg} . \mathrm{m}^{-}$ ${ }^{3}$ during one hour and a half. The oil was recovered and stored in amber flasks and the leaves were dried in an oven with air circulation at $318 \mathrm{~K}$ for $48 \mathrm{~h}$.

\section{Supercritical Extraction}

Samples of $0.1 \mathrm{~kg}$ of dried and milled material with average particle diameter of $1.3 \times 10^{-4} \mathrm{~m}$ and solid density of $1297 \mathrm{~kg} \cdot \mathrm{m}^{-3}$ were used for extraction of non-volatile compounds in automated equipment for supercritical fluid extraction previously described by Scopel et al. (2016) using a $5 \times 10^{-4} \mathrm{~m}^{-3}$ extraction vessel. The extractor pressure was kept constant at 15 $\mathrm{MPa}$ and the temperatures assayed were $313 \mathrm{~K}$ and 333 $\mathrm{K}$. The solvent used was carbon dioxide (Air Products, $99.9 \%$ ) with flow rate of $1.59 \times 10^{-4} \mathrm{~kg} \mathrm{~s}^{-1}, 2.77 \mathrm{x}$ $10^{-4} \mathrm{~kg} \mathrm{~s}^{-1}$ and $4.16 \times 10^{-4} \mathrm{~kg} \mathrm{~s}^{-1}$ through the extraction vessel. The choice of these conditions was based on results presented by Moura et al.(2012).

\section{Chemical Analysis \\ Composition and identification of the essential oil components}

The composition of the essential oil obtained by steam distillation was determined by GC-MS on an Agilent 7890A gas chromatograph equipped with an Agilent 5975C mass spectrometer (Agilent Technologies, USA). The injector used was in split mode (1:55) at $523 \mathrm{~K}$. The capillary column used was a HP-5MS (30 m x $250 \mu \mathrm{m}$ i.d., $0.25 \mu \mathrm{m}$ phase thickness, Agilent Technologies, USA), coated with 5\% phenyl methyl silane. The oven temperature was held at 333 $\mathrm{K}$ for $8 \mathrm{~min}$, raised to $453 \mathrm{~K}$ at $3 \mathrm{Kmin}^{-1}$ rate, to 523 $\mathrm{K}$ at $20 \mathrm{Kmin}^{-1}$, then held for $10 \mathrm{~min}$. Carrier gas was helium, flow rate $0.8 \mathrm{~mL} \mathrm{~min}^{-1}$; interface temperature $523 \mathrm{~K}$; MS mode EI $(70 \mathrm{eV})$; acquisition mass range, $\mathrm{m} / \mathrm{z}$ 40-450.The components of the oil were identified by comparison of their mass spectra with those stored in the GC-MS databases (Adams, 2007).

\section{Analysis of phenolic compounds}

Guava leaves have been reported to contain many different kinds of phenolic compounds (Nantitanon et al., 2010; Diaz-de-Cerio et al., 2016). The identification and quantification of phenolic compounds in the extracts obtained through supercritical fluid extraction 
were performed using an HPLC model 1200 Series(Agilent Technologies, USA) equipped with an UV-VIS detector set at $345 \mathrm{~nm}$ and a C18 column $(4.6 \times 250 \mathrm{~mm} \times 5 \mu \mathrm{m})$. The method is based on the description presented by Kumazawa et al. (2003). The elution solvents were Milli-Q (Millipore) water (A) and acetonitrile (Merck) (B), both with 2\% glacial acetic acid (Merck), in a linear gradient from 20\% to $80 \% \mathrm{~B}$ in $90 \mathrm{~min}$ with $1 \mathrm{~mL} \mathrm{~min}{ }^{-1}$ flow rate. Phenolic compounds were identified by comparison of their retention time values and UV spectra with those of known standards and determined by peak areas from the chromatograms. For the reference analytical curves, quercetin and ferulic acid were dissolved in acetonitrile:water $(1: 1, \mathrm{v} / \mathrm{v})$ to achieve concentrations from 250 to $0.25 \mu \mathrm{g} \mathrm{mL}^{-1}$.

\section{Antioxidant Activity}

The antioxidant activity of extracts from guava was determined by the DPPH method (Brand-Williams et al., 1995) based on the capture of the free radical DPPH (2,2-diphenyl-1-picryl-hydrazil) with the modifications proposed by Rufino et al.(2007). This method is based on the capture of DPPH (Sigma $\left.{ }^{\circledR}\right)$ by antioxidants, producing a decrease in absorbance of a working solution of $0.06 \mathrm{M}$. When DPPH reacts with an antioxidant compound, it is reduced, changing the solution color from deep purple to a light yellow. The analyses were performed in a spectrophotometer (Biospectro SP-220, Brazil) where the absorbance was read at $515 \mathrm{~nm}$ after $60 \mathrm{~min}$. The parameter $\mathrm{EC}_{50}$, which reflects $50 \%$ depletion of DPPH free-radical, was calculated and expressed in terms of grams of extract of $P$. guajava per gram of DPPH in the reaction medium.

\section{Mathematical Modeling}

The mathematical model used to fit the experimental data for steam distillation and supercritical fluid extraction was proposed by Sovová (2005) and previously used by Xavier et al. (2011) with modifications. In this model, the solute is assumed to be homogeneously distributed in the solid particles. The easily accessible solute from broken cells near the surface is transferred directly to the fluid-phase, while the solute from intact cells diffuses internally and then to the fluid-phase.

Xavier et al. (2011) presented the following expression for the mass fraction in fluid-phase:

$$
\mathrm{Y}=\mathrm{Y}^{*} \text {, for } \mathrm{x}>\mathrm{x}_{\mathrm{k}}
$$

being $\mathrm{Y}^{*}$ the equilibrium fluid-phase mass fraction, and $x_{k}$ the mass fraction associated with inaccessible solute inside the solid-phase. At this stage, the free solute from broken cells is removed, considering the hypothetical case with negligible external mass transfer.

The second period of extraction is characterized by the diffusion of the inaccessible solute from the innermost strata of the plant material. Xavier et al. (2011) presents the following expression for the mass fraction in the solid-phase:

$$
\mathrm{X}=\mathrm{X}_{0} \mathrm{e}^{-\mathrm{K}_{2} \mathrm{t}}
$$

and for the mass fraction in fluid phase:

$$
\mathrm{Y}(\mathrm{z}, \mathrm{t})=\frac{(1-\varepsilon)}{\varepsilon} \frac{\rho_{\mathrm{s}}}{\rho_{\mathrm{f}}} \mathrm{x}_{\mathrm{o}}\left\{\mathrm{e}^{-\mathrm{K}_{2}\left(\mathrm{t}-\frac{\mathrm{z} \varepsilon}{\mathrm{u}}\right)}-\mathrm{e}^{-\mathrm{K}_{2} \mathrm{t}}\right\}, \text { for } \mathrm{x} \leq \mathrm{x}_{\mathrm{k}}
$$

where $\varepsilon$ is the bed porosity, $\rho_{s}$ is the solid density $\rho_{f}$ is the solvent density, $z$ is axial co-ordinate, $t$ is time, $u$ is superficial fluid velocity, and $K_{2}$ is a parameter defined by:

$\mathrm{K}_{2}=\frac{\mathrm{k}_{\mathrm{s}} \mathrm{a}_{0}}{(1-\varepsilon)}$

considering $\mathrm{k}$ the solid-phase mass transfer coefficient and $a_{0}$ the specific surface area per unit volume of particle.

We assume that the first stage ends when $x=x$ and we associate the time $\tau$ with this condition. Based on the hypothesis that extraction curves are associated with the non-existence of interaction between solute and matrix, the model used is described by the following equation for the extracted mass collected in each of the two extraction periods:

$$
\mathrm{M}(\mathrm{t})=\left\{\begin{array}{l}
\mathrm{K}_{1} \mathrm{t}, \quad \mathrm{t} \leq \tau \\
\text { and } \\
\mathrm{M}^{*}+\left\{\left[\mathrm{M}_{\infty}-\mathrm{M}^{*}\right]\left[1-\mathrm{e}^{-\mathrm{K}_{2}(\mathrm{t}-\tau)}\right]\right\}, \quad \mathrm{t} \geq \tau
\end{array}\right.
$$

$M(t)$ is the mass of extract, $M^{*}$ is the mass of easily accessible solute and $M_{\infty}$ is the maximum value for the extract obtained in each extraction. The extraction curve is a linear function of the time for the first step in the extraction and exponential for the second period. The model parameters $\mathrm{K}_{1}$ and $\mathrm{K}_{2}$ are associated with the period of easily accessible solute extraction and the inner solute cell extraction, respectively. The parameter $K_{l}$ is expressed by:

$$
\mathrm{K}_{1}=\dot{\mathrm{m}} \mathrm{Y}^{*}
$$

where $\mathrm{m}$ is the solvent flow rate. 


\section{Statistical analysis}

The mathematical modeling and evaluation of goodness of fit were performed with the MATLAB R2014a (MathWorks, Massachusetts, USA) software. The sum of squares due to error (SSE), root mean squared error (RMSE), as well as both coefficient of multiple determination $\left(\mathrm{R}^{2}\right)$, and adjusted coefficient of multiple determination $\left(\mathrm{R}^{2}{ }_{\text {adj }}\right)$ were calculated for each extraction condition.

\section{RESULTS AND DISCUSSIONS}

\section{Essential oil chemical composition}

The average yield of essential oil from the leaves of $P$. guajava obtained by steam distillation was 0.56 $\mathrm{g} \mathrm{kg}^{-1}$ on a fresh weight basis. This result was lower than the ones reported by other authors using hydro distillation (Khadhri et al., 2014; da Silva et al., 2016; Soliman et al., 2016), steam distillation (Adam et al., 2011) and supercritical fluid extraction (Moura et al., 2012). The composition of the oil isin accordance with the above mentioned published data, with slight differences. The volatile compounds identified in the essential oil of P. guajava are presented in Table 1. The main compounds identified (in bold) were E-caryophyllene $(20.50 \%), \quad \beta$-selinene $(16.64 \%)$, $\alpha$-selinene (16.09\%), selin-11-en-4- $\alpha$-ol (13.31\%) and E-nerolidol (7.61\%). These compounds were found by other workers (Pino et al., 2001, Ogunwande et al. 2003) using hydrodistillation and the composition presented by them is very similar to the one we obtained using steam distillation. However, Ogunwande et al (2003) identified a high percentage of limonene that was not found in the volatile extract obtained in our analysis. The authors who used the supercritical extraction to obtain essential oil (Moura et al., 2012) also found $\beta$-caryophyllene, $\beta$-selinene and $\alpha$-selinene as major, although Moura et al. (2012) identified the presence of globulol and diocthylphthalate also as major compounds. Sagrero-Nieves et al. (1994) identified delta-selinene, allo-aromadendrene and caryophillene epoxide also as major compounds. These compounds were not identified in the essential oil obtained in this study. Variations in the composition are expected since it depends on several factors: phenological state, geographical factors (location), ecological factors (habitat), genetic variability (chemotype), the extraction process, etc (Bandoni, 2003).

\section{Phenolic composition of supercritical extracts}

In this work, the phenolic compounds from the extracts obtained by supercritical fluid extraction were determined using HPLC. The sample peaks were identified by matching retention time (Rt) of phenolic standards of interest, namely ferulic acid (Rt $=6.84$ $\mathrm{min})$ and quercetin $(\mathrm{Rt}=14.47 \mathrm{~min})$ and quantified
Table 1. GC-MS of volatile oil extracted by steam distillation.

\begin{tabular}{|c|c|c|}
\hline Compound $^{\mathrm{a}}$ & $\mathbf{I R}^{\mathbf{b}}$ & $A(\%)^{c}$ \\
\hline$\alpha$-pinene & 931 & 0.05 \\
\hline benzaldehyde & 958 & 0.89 \\
\hline myrcene & 991 & 0.07 \\
\hline sylvestrene & 1028 & 0.21 \\
\hline 1,8-cineole & 1031 & 1.46 \\
\hline Z- $\beta$-ocimene & 1039 & 0.62 \\
\hline E- $\beta$-ocimene & 1049 & 0.18 \\
\hline$\gamma$-terpinene & 1058 & 0.05 \\
\hline linalool & 1100 & 0.07 \\
\hline terpinen-4-ol & 1177 & 0.04 \\
\hline 3Z-hexenyl butanoate & 1188 & 0.08 \\
\hline$\alpha$-terpineol & 1190 & 0.30 \\
\hline Safrole & 1288 & 0.05 \\
\hline$\alpha$-cubebene & 1351 & 0.04 \\
\hline$\alpha$-copaene & 1377 & 0.36 \\
\hline E-caryophyllene & 1430 & 20.50 \\
\hline$\alpha$-humulene & 1459 & 4.66 \\
\hline 4,5-di-epi-Aristolochene & 1472 & 0.57 \\
\hline$\beta$-selinene & 1497 & 16.64 \\
\hline$\alpha$-selinene & 1507 & 16.09 \\
\hline$\beta$-bisabolene & 1512 & 0.46 \\
\hline 7-epi- $\alpha$-Selinene & 1523 & 0.62 \\
\hline$\alpha$-cadinene & 1527 & 0.05 \\
\hline E-nerolidol & 1572 & 7.61 \\
\hline caryophyllenyl alcohol & 1574 & 0.28 \\
\hline 1-epi-Cubenol & 1634 & 1.09 \\
\hline$\delta$-muurolol & 1655 & 2.12 \\
\hline selin-11-en-4- $\alpha-0 \mid$ & 1668 & 13.31 \\
\hline$\alpha$-bisabolol & 1690 & 0.09 \\
\hline 2E,6Z-farnesol & 1724 & 0.02 \\
\hline benzyl benzoate & 1766 & 0.09 \\
\hline Total identification & \multicolumn{2}{|c|}{$88.64 \%$} \\
\hline
\end{tabular}

a: compounds identified with the library Adams (2007).

'IR: retention index calculated for a range of alkanes.

${ }^{\mathrm{c}} \mathrm{A}(\%)$ : percent area of each peak relative to the total area of the chromatogram.

by external standard methods. The linear regression analysis showed a good fit to the analytical curves reflected by $\mathrm{R}^{2}$ values greater than 0.99 for both standards. The chromatogram of the standards and extracts at $313 \mathrm{~K}$ and $333 \mathrm{~K}$ are shown in Figure 1. The analysis of phenolic compounds in the P. guajava extracts is shown on Table 2, where the results are presented as means of two replicates \pm standard deviation.

There was no significant difference between the extracts obtained with different solvent flows at the same temperature. The concentration of ferulic acid and quercetin showed a slight decrease with the increase in the temperature at constant pressure of $15 \mathrm{MPa}$. The chromatograms also indicate a higher concentration of

Table 2. Concentration of quercetin and ferulic acid in extracts of P. guajava.

\begin{tabular}{ccc}
\hline Sample & $\begin{array}{c}\text { Quercetin } \\
\left(\boldsymbol{\mu g} \mathbf{g}^{-1}\right)\end{array}$ & $\begin{array}{c}\text { Ferulic acid } \\
\left(\boldsymbol{\mu g} \mathbf{g}^{-1}\right)\end{array}$ \\
\hline $313 \mathrm{~K}$ & $15.74 \pm 0.41$ & $53.94 \pm 0.78$ \\
$333 \mathrm{~K}$ & $11.22 \pm 0.08$ & $45.16 \pm 0.45$ \\
\hline
\end{tabular}


other possible unidentified phenolic compounds in the extract obtained at $313 \mathrm{~K}$. This result can be attributed to the reduced solvency power of $\mathrm{CO}_{2}$ with an isobaric increase of temperature that consequently reduces the mass of extract. While in the present paper the increase of temperature showed an unfavorable effect on the concentration of phenolic compounds, other authors presented an opposing result. According to CastroVargas et al. (2011), the temperature effect showed an increase in total phenolic content from 313 to $333 \mathrm{~K}$ at 10 and at $20 \mathrm{MPa}$. It is known that higher temperatures can improve the extraction by promoting the solubility of the solute. Therefore, as shown by Liu et al. (2011), an increase in temperature can have either a positive or a negative effect on the extraction of flavonoids.

\section{Antioxidant activity}

The supercritical fluid extracts presented an overall higher antioxidant activity than the essential oil, which was already reported to be a moderate antioxidative agent (Lee et al., 2012; El-Ahmady et al., 2013). These results indicate a stronger antioxidant activity than previously reported by Qian and Nihorimbere (2004). The antioxidant activity of plant extracts is usually
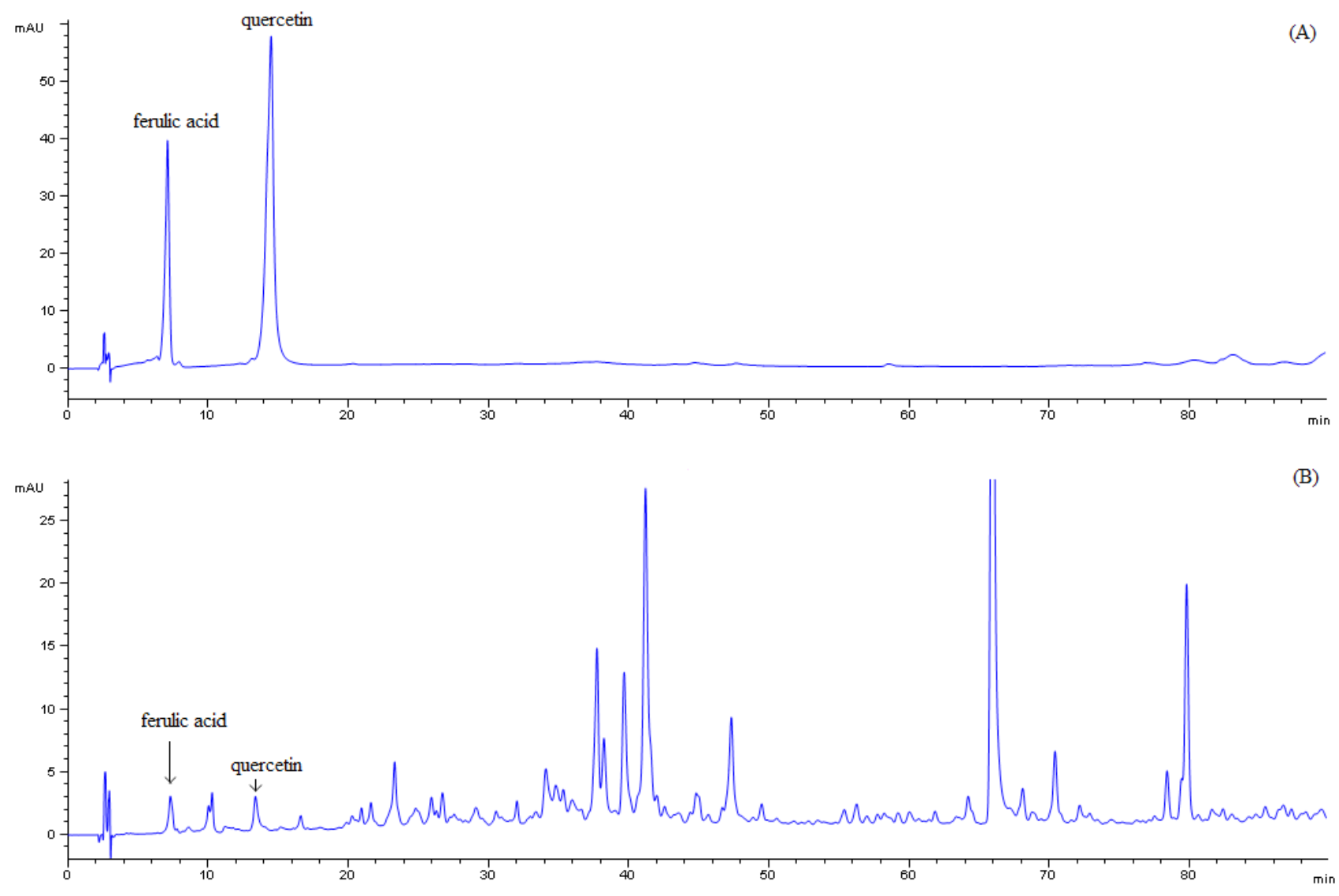

(B)

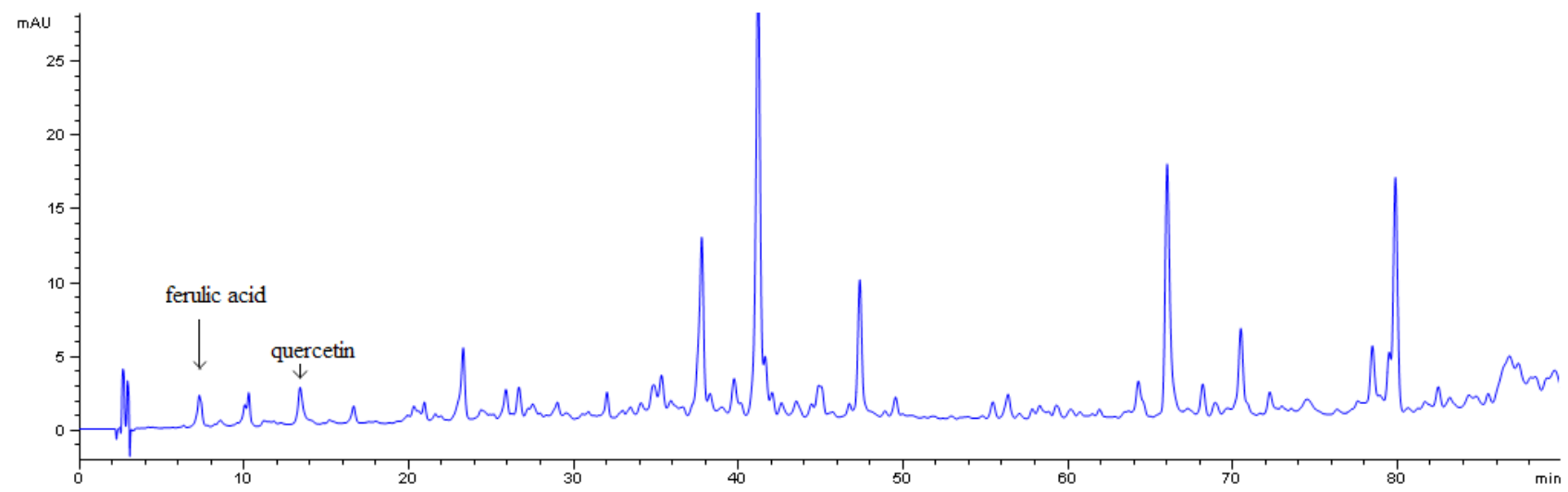

Figure 1. HPLC chromatographs of (A) standards, (B) extract obtained at $313 \mathrm{~K}$ and (C) extract obtained at $333 \mathrm{~K}$ : (7.06) ferulic acid; (14.47) quercetin. 
attributed to phenolic compounds, such as ferulic acid and quercetin (Croft, 1998). Several authors already presented a positive correlation between phenolic compounds and antioxidant activity for $P$. guajava extracts (Chen and Yen, 2007; Castro-Vargas et al., 2010; Corrêa et al., 2011; Fernandes et al., 2014). However, the extract obtained at $333 \mathrm{~K}$, which had a lower concentration of quercetin and ferulic acid, was more efficient than that obtained at $313 \mathrm{~K}$, as the lower concentration $(17.47 \mathrm{~g})$ was able to sequester $1.00 \mathrm{~g} \mathrm{DPPH}$ (Table 3). Quercetin and ferulic acid do not seem to be significantly responsible for the antioxidant activity of the extracts. Other complex phenolic compounds unidentified may also provide the antioxidant activity. Zheng and Wang (2001)noted that the antioxidant activity in plants extracts cannot be easily explained, since synergistic and antagonistic actions of constituents in the multicomponent mixture can affect the extract's efficiency.

Table 3. Antioxidant activity of the extracts obtained from $P$. guajava by steam distillation and supercritical fluid extraction.

\begin{tabular}{cc}
\hline Sample & EC $_{50}\left(\mathbf{g}_{\text {extract }} \mathbf{g}_{\mathbf{D P P H}}{ }^{-1}\right)$ \\
\hline Steam distillation & \\
Essential Oil & $693.21 \pm 13.02$ \\
Supercritical extraction & \\
$313 \mathrm{~K}$ & $19.13 \pm 0.15$ \\
$333 \mathrm{~K}$ & $17.47 \pm 0.42$ \\
\hline
\end{tabular}

\section{Extraction curves and mathematical modeling}

The unknown parameters in the model were adjusted using the experimental data from the supercritical fluid extraction and steam distillation equipments. The modeling of the steam distillation is shown in Figure 2 with the calculated values for the parameters from Equation 5 .These parameters were $\tau=857 \mathrm{~s}, Y^{*}=$ $5.27 \times 10^{-3}$ and $k_{s}=1.31 \times 10^{-8} \mathrm{~m} . \mathrm{s}^{-1}$ considering leaves with planar geometry.

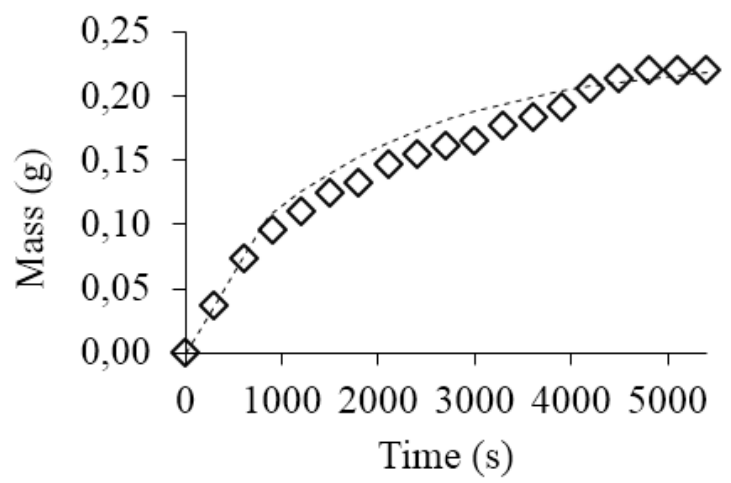

Figure 2. Steam extraction mass vs. time curve. $(\diamond)$ Experimental data; (---) Eqs. (5) with parameters $\mathrm{K}_{1}=$ $1.23 \times 10^{-8} \mathrm{~kg} \mathrm{~s}^{-1}, \mathrm{~K}_{2}=5.08 \times 10^{-4} \mathrm{~s}^{-1}, \mathrm{M}_{\infty}=0.221 \times 10^{-3}$ $\mathrm{kg}$ and $\tau=857 \mathrm{~s}\left(\mathrm{SSE}=7.91 \times 10^{-3}, \mathrm{RMSE}=8.54 \mathrm{x}\right.$ $10^{-3}, \mathrm{R}^{2}{ }_{\text {adj }}=0.9786$ and $\mathrm{R}^{2}=0.9845$ ) for a $2.33 \times 10^{-4}$ $\mathrm{kg} \mathrm{s}^{-1}$ flow.
The experimental data and the results for the mathematical modeling of the supercritical extraction at $313 \mathrm{~K}$ and $333 \mathrm{~K}$ at the pressure of $15 \mathrm{MPa}$ are shown in Figure 3 and Figure 4 and the numerical values for the parameters in Table 4 . These parameters were estimated by the least squares method with a NelderMead (SIMPLEX) algorithm in order to minimize the objective function using the software MATLAB. The amount of extract obtained was lower than that reported previously by other authors for supercritical extraction of parts of $P$. guajava under similar operational conditions, using ethanol as cosolvent. The global yields obtained by Moura et al., (2012) at

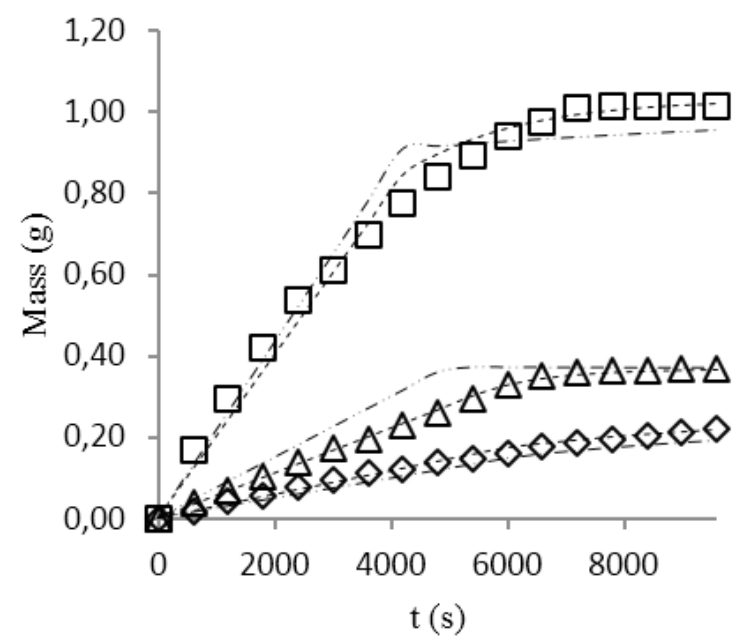

Figure 3. Supercritical extraction mass $v s$. time curves at $313 \mathrm{~K}$ and $15 \mathrm{MPa}$. Flow rate conditions: $(\diamond) 1.59$ x $10^{-4} \mathrm{~kg} \mathrm{~s}^{-1} ;(\triangle) 2.77 \times 10^{-4} \mathrm{~kg} \mathrm{~s}^{-1} ;(\square) 4.16 \times 10^{-4}$ $\mathrm{kg} \mathrm{s}^{-1} ;(---)$ Sovová model - Eqs. (1) with parameters from Table 4; (-.-) Preditive model - Eqs. (7) with parameters from Table 5.

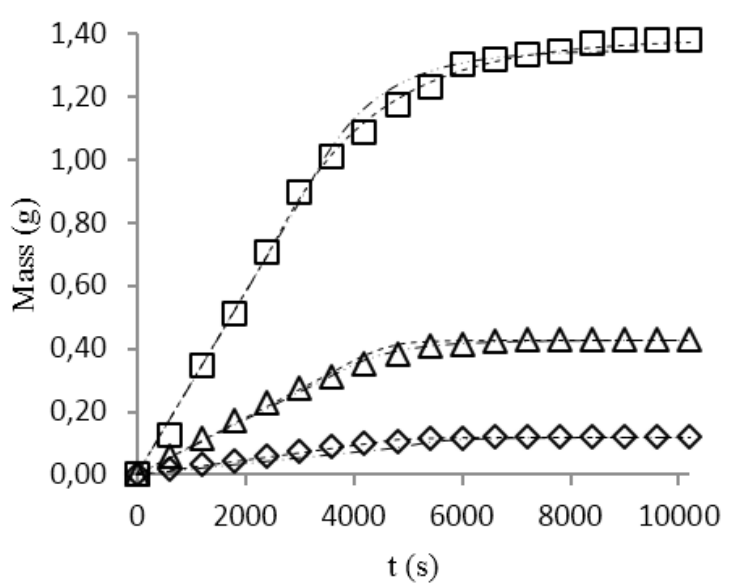

Figure 4. Supercritical extraction mass vs. time curves at $333 \mathrm{~K}$ and $15 \mathrm{MPa}$. Flow rate conditions: $(\diamond) 1.59$ x $10^{-4} \mathrm{~kg} \mathrm{~s}^{-1} ;(\triangle) 2.77 \times 10^{-4} \mathrm{~kg} \mathrm{~s}^{-1} ;(\square) 4.16 \times 10^{-4}$ $\mathrm{kg} \mathrm{s}^{-1}$; (---) Sovová model - Eqs. (1) with parameters from Table 4; (-.-) Preditive model - Eqs. (7) with parameters from Table 5. 
Table 4. Parameters from the mathematical model for extraction curves fitted to experimental data for supercritical fluid extraction of P. guajava leaves at $313 \mathrm{~K}$ and $333 \mathrm{~K}$.

\begin{tabular}{|c|c|c|c|c|c|c|c|c|c|c|c|}
\hline $\begin{array}{c}\mathbf{T} \\
(\mathbf{K})\end{array}$ & $\begin{array}{c}\text { Flow } \\
\text { rate } \\
\times 10^{4} \\
\left(\mathbf{k g ~ s}^{-1}\right)\end{array}$ & $\begin{array}{c}\mathbf{M}_{\infty} \\
\times 10^{3} \\
(\mathbf{k g})\end{array}$ & $\begin{array}{c}\mathrm{K}_{1} \\
\times 10^{8} \\
\left(\mathrm{~kg} \mathrm{~s}^{-1}\right)\end{array}$ & $\begin{array}{c}\mathbf{K}_{2} \\
\times \mathbf{1 0}^{4} \\
\left(\mathbf{s}^{-1}\right)\end{array}$ & $\begin{array}{c}\tau \\
\times \mathbf{1 0}^{-3} \\
(\mathbf{s})\end{array}$ & $\begin{array}{c}Y^{*} \\
\times 10^{4}\end{array}$ & $\begin{array}{c}\mathbf{k}_{\mathbf{s}} \\
\times 10^{9} \\
(\mathbf{m} / \mathbf{s})\end{array}$ & $\begin{array}{l}\text { SSE } \\
\times 10^{3}\end{array}$ & $\begin{array}{c}\text { RMSE } \\
\times 10^{2}\end{array}$ & $\mathbf{R}^{2}$ adj & $\mathbf{R}^{2}$ \\
\hline \multirow{3}{*}{313} & 4.16 & 1.0142 & 20.10 & 5.36 & 4.20 & 4.83 & 1.83 & 21.95 & 3.59 & 0.9887 & 0.9911 \\
\hline & 2.77 & 0.369 & 5.58 & 8.60 & 5.17 & 2.01 & 2.93 & 0.39 & 0.48 & 0.9980 & 0.9985 \\
\hline & 1.59 & 0.221 & 2.90 & 2.32 & 5.90 & 1.83 & 0.78 & 0.62 & 0.60 & 0.9924 & 0.9940 \\
\hline \multirow{3}{*}{333} & 4.16 & 1.347 & 28.80 & 5.47 & 2.59 & 6.93 & 1.86 & 6.06 & 1.84 & 0.9981 & 0.9986 \\
\hline & 2.77 & 0.428 & 9.05 & 21.10 & 4.20 & 3.27 & 7.19 & 2.56 & 1.19 & 0.9923 & 0.9948 \\
\hline & 1.59 & 0.119 & 2.36 & 17.00 & 4.80 & 1.48 & 5.78 & 0.13 & 0.27 & 0.9970 & 0.9972 \\
\hline
\end{tabular}

the same pressure $(15 \mathrm{MPa})$, using leaves, seem to be between $1.8 \%$ and $2 \%$ at $313 \mathrm{~K}$ and between $2.6 \%$ and $2.8 \%$ at $328 \mathrm{~K}$. It should be noted that the maximum yields obtained in our experiments were $1.02 \%$ at 313 $\mathrm{K}$ and $1.37 \%$ at $333 \mathrm{~K}$, both for high solvent flow. However, these results are expressed per unit mass of plant in which the essential oil was already extracted during the steam distillation.

The mathematical model used here is based on the concept of broken and intact cells; it is suited to fit experimental data whose behavior is described by two temporal phases, the first one governed by phase equilibrium and the second one governed by internal diffusion from particles. In the first phase, a straight line reproduces the behavior of the extraction curve with a constant extraction rate, where the main mass transfer mechanism is convection. The solubility is established from the slope of this line for all extraction conditions carried out and is associated with the parameter $\mathrm{K}_{1}$. It is convenient to clarify that the solubility measured by a dynamic method is related to a process parameter (Scopel et al., 2016), whereas the solubility calculated and/or measured from VLE experiments assures the isofugacity condition, resulting in a more reliable value of the substance property. According to Johannsen and Brunner (1994), dynamic methods often result in different values for the equilibrium solubility than static methods because of problems with achieving equilibrium. The significant difference may be attributed to interactions of the nonvolatiles with the vegetable matrix, as well as with other non-volatile compounds present in the extracts. The difference between the behavior of the equilibrium mass fraction $\left(Y^{*}\right)$ and the solubility defined by the isofugacity condition at constant temperature justifies why $K_{l}$ values reported in Table 2 are not proportional to the values of flow rate. In the second period, an exponential curve represents the extraction and the mathematical modeling involves the parameter $\mathrm{K}_{2}$, which is associated with the solid-phase coefficient. The mass transfer in the second phase is controlled by the diffusion inside of the particles. It is important to remember that the crossing point is a fictional time when mass transfer from intact cells begins, also known as the shift of the second part of the extraction curve.

The extraction curves with solvent flow equal to $1.59 \times 10^{-4} \mathrm{~kg} \mathrm{~s}^{-1}$ and $2.77 \times 10^{-4} \mathrm{~kg} \mathrm{~s}^{-1}$ at $313 \mathrm{~K}$ presented a similar kinetic behavior. Both extractions were limited by the diffusion phenomenon and presented similar maximum mass of extract $(0.24 \mathrm{~g})$. The highest solvent flow condition $\left(4.16 \times 10^{-4} \mathrm{~kg} \mathrm{~s}^{-1}\right)$ presented two well delimited extraction phases and also the highest amount of extract at the temperature of $313 \mathrm{~K}$ $(1 \mathrm{~g})$. The extraction curves at $333 \mathrm{~K}$ presented very distinct behaviors. The lowest solvent flow extraction was similar to the extraction with $1.59 \times 10^{-4} \mathrm{~kg} \mathrm{~s}^{-1}$ at $313 \mathrm{~K}$ and resulted in a slightly lower efficiency. The extraction at flow equal to 2.77 and $4.16 \times 10^{-4}$ $\mathrm{kg} \mathrm{s}^{-1}$ had well delimited extraction phases. Although both extractions reached the end of the two phases at the same time, the extraction with $4.16 \times 10^{-4} \mathrm{~kg}$ $\mathrm{s}^{-1}$ resulted in a considerably higher amount of extract $(1.38 \mathrm{~g})$ than the extraction with solvent flow of 2.77 x $10^{-4} \mathrm{~kg} \mathrm{~s}^{-1}(0.428 \mathrm{~g})$. These patterns are reflected by the results of the parameters $K_{l}$ and $K_{2}$ obtained for each extraction. Faster extractions presented higher values of $K_{l}$, that are associated with the solubility and slower extractions. The values of $K_{2}$ were expected to be similar; the parameter $K_{2}$ is expressed as a function of the solid-phase coefficient associated with the transport of the solute inside the solid particle. According to the numerical results for the tested conditions, this coefficient was not strongly influenced by the external solvent flow, but had its value increased as the temperature rose. The analysis of the results of the values obtained for the statistical indicators (RMSE, SSE, $\mathrm{R}^{2}$ and $\mathrm{R}_{\text {adj }}{ }^{2}$ ) shown in Table 4 indicated that the mathematical model, based on mass transfer fundamentals, fitted very well the experimental data. The minor variations can be the result of the numerical method applied to adjust the parameters, as well as the variations inherent to experimental data.

Using the available experimental data, we proposed a predictive four-parameter model with dependence on temperature and solvent mass flow. For this the following relation was considered for each parameter $\left(P_{i}\right)$ of Tables 4 and 5: 
Table 5. Parameters from the predictive model for extraction curves fitted to experimental data for supercritical fluid extraction of $P$. guajava leaves at $313 \mathrm{~K}$ and $333 \mathrm{~K}$.

\begin{tabular}{|c|c|c|c|c|c|c|c|c|}
\hline $\begin{array}{c}\mathbf{T} \\
(\mathbf{K})\end{array}$ & $\begin{array}{c}\text { Flow rate } \times 10^{4} \\
\left(\mathrm{~kg} \mathrm{~s}^{-1}\right)\end{array}$ & $\begin{array}{c}\mathrm{K}_{1} \times 10^{8} \\
\left(\mathrm{~kg} \mathrm{~s}^{-1}\right)\end{array}$ & $\begin{array}{c}K_{2} \times 10^{4} \\
\left(\mathrm{~s}^{-1}\right)\end{array}$ & $\tau \times 10^{-3}(\mathrm{~s})$ & $\mathrm{SSE} \times 10^{3}$ & RMSE $\times 10^{2}$ & $\mathbf{R}^{2}$ adj & $\mathbf{R}^{2}$ \\
\hline \multirow{3}{*}{313} & 4.16 & 21.68 & 1.09 & 4.20 & 59.78 & 6.53 & 0.9472 & 0.9662 \\
\hline & 2.77 & 7.51 & 1.33 & 4.96 & 37.83 & 5.20 & 0.9161 & 0.9367 \\
\hline & 1.59 & 2.48 & 1.75 & 6.24 & 5.34 & 1.95 & 0.9945 & 0.9951 \\
\hline \multirow{3}{*}{333} & 4.16 & 28.83 & 8.39 & 3.24 & 21.41 & 3.91 & 0.9916 & 0.9943 \\
\hline & 2.77 & 8.77 & 10.26 & 3.83 & 1.01 & 0.85 & 0.9974 & 0.9979 \\
\hline & 1.59 & 1.80 & 13.51 & 4.81 & 2.53 & 1.35 & 0.9564 & 0.9606 \\
\hline
\end{tabular}

$\mathrm{Pi}=\mathrm{a}_{\mathrm{i}}[\mathrm{T}]^{\mathrm{n}_{\mathrm{i}}}[\dot{\mathrm{m}}]^{\mathrm{j}_{\mathrm{i}}}$

where $\mathrm{i}=1$ to $4, \mathrm{P}_{1}$ is $\mathrm{K}_{1}, \mathrm{P}_{2}$ is $\mathrm{K}_{2}, \mathrm{P}_{3}$ is $\tau$ and $\mathrm{P}_{4}$ is $\mathrm{M} \infty$. From the use of experimental data and the values presented in Table 4, the coefficient $a_{\mathrm{i}}$ and the exponents $n_{i}$ and $j_{i}$ were calculated by the least squares method resulting in $a_{1}=3.042 \times 10^{-1} \mathrm{~kg}^{-0.54} \mathrm{~s}^{0.54} \mathrm{~K}^{1.517}$, $\mathrm{n}_{1}=-1.517, \quad \mathrm{j}_{1}=1.054 \quad a_{2}=1.823 \times 10^{-5} \mathrm{~kg}^{0.923} \mathrm{~s}^{-1.923} \mathrm{~K}^{0.652}$, $\mathrm{n}_{2}=-0.652, \quad \mathrm{j}_{2}=-0.923, \quad a_{3}=9.131 \times 10^{13} \mathrm{~kg}^{0.411} \mathrm{~s}^{0.589} \mathrm{~K}^{4.205}$, $\mathrm{n}_{3}=-4.205, \quad \mathrm{j}_{3}=-0.411, \quad a_{4}=1.269 \times 10^{-5} \mathrm{~kg}^{-1.381} \mathrm{~s}^{2.381} \mathrm{~K}^{-2.328}$, $\mathrm{n}_{4}=2.328$ and $\mathrm{j}_{4}=2.381$. Therefore, using equation 7 , it is possible to obtain the value for each of the parameters and consequently makes possible the forecast of the extraction curve. These parameters are reasonable within the range studied and, when fed to equation 5 , they yield results that, compared to the experimental data, produce good statistical indicators, whose values are presented in Table 5, showing that the model developed is reliable for predictions of the phenomena.

\section{CONCLUSIONS}

Conventional solvents (e.g., methanol) can be successfully replacedby nontoxic solvents such as water and $\mathrm{CO}_{2}$ to obtain antioxidant extracts, rich in polyphenols, though a sequential process. Another advantage of this approach is the recovery of P. guajava essential oil. Although obtained as a byproduct, the essential oil is an interesting nutraceutical alternative due to its significant concentration of oxygenated monoterpenes and sesquiterpenes. Supercritical fluid extraction is part of a proposal for a sustainable use of this popular southern Brazilian plant, extracts of which have proven activities. The $\mathrm{CO}_{2}$ flow showed to be an important variable in the supercritical extraction process for the experiments carried out. The twofold increase of solvent flow quadrupled the mass of extract obtained for the operation at $313 \mathrm{~K}$ and for the $333 \mathrm{~K}$ condition the gain was 11 times more mass. The model used in this study described satisfactorily the experimental extraction curve, enabling the determination of the values of the adjustable parameters, which provide important knowledge about the steam distillation process and supercritical extraction of guava leaves.

\section{NOMENCLATURE}

$\mathrm{a}_{0} \quad$ Specific surface area per volume, $\mathrm{m}^{2} \mathrm{~m}^{-3}$ $\mathrm{K}_{1} \quad$ Parameter defined by Eq. 2, $\mathrm{kg} \mathrm{s}^{-1}$

$\mathrm{K}_{2} \quad$ Parameter defined by Eq. 3, $\mathrm{s}^{-1}$

$\mathrm{k}_{\mathrm{s}} \quad$ Solid phase coefficient, $\mathrm{m} \mathrm{s}^{-1}$

$\mathrm{M}(\mathrm{t}) \quad$ Mass of extract, $\mathrm{kg}$

$\mathrm{M}_{\infty} \quad$ Maximum value of the mass extracted, $\mathrm{kg}$

$\mathrm{M}^{\infty} \quad$ Mass of easily accessible solute, $\mathrm{kg}$

m Solvent flow rate, $\mathrm{kg} \mathrm{s}^{-1}$

RMSE Root mean square deviation

$\mathrm{R}^{2} \quad$ Coefficient of determination

$\mathrm{R}^{2}$ adj $\quad$ Adjusted coefficient of determination

SSE Sum of squared errors

$\mathrm{t} \quad$ Time, $\mathrm{s}$

$\mathrm{u} \quad$ Superficial fluid velocity, $\mathrm{m} / \mathrm{s}$

$\mathrm{x} \quad$ Mass fraction in the solid-phase, $\mathrm{kg} \mathrm{kg}^{-1}$

$\mathrm{x}_{\mathrm{k}} \quad$ Inaccessible solute mass fraction in the solid-phase, $\mathrm{kg} \cdot \mathrm{kg}^{-1}$

$\begin{array}{ll}\mathrm{z} & \text { Axial co-ordinate, } \mathrm{m} \\ \mathrm{Y}^{*} & \text { Equilibrium fluid-phase mass fraction, }\end{array}$ $\mathrm{kg} \mathrm{kg}^{-1}$

Greek Letters

$\varepsilon \quad$ Bed void fraction, dimensionless

$\rho_{\mathrm{s}} \quad$ Solid density, $\mathrm{kg} \cdot \mathrm{m}^{-3}$

$\rho_{\mathrm{f}} \quad$ Solvent density, kg.m ${ }^{-3}$

$\tau \quad$ Time associated with the removal of all easily accessible solute, $\mathrm{s}$

\section{ACKNOWLEDGEMENTS}

The authors thank CNPq.

\section{REFERENCES}

Adam, F., Vahirua-Lechat, I., Deslandes, E., and Menut, C., Aromatic plants of French Polynesia. V. Chemical composition of essential oils of leaves of Psidium guajava L. and Psidium cattleyanum Sabine. J. Essent. Oil Res., 23(1), 98-101 (2011). https://doi.org/10.1080/10412905.2011.9700433

Adams, R. P., Identification of essential oil components by gas chromatography/mass spectrometry.4th Ed., Allured. Carol Stream, Ilinois (2007). 
Aslani, B. A., and Ghobadi, S.; Studies on oxidants and antioxidants with a brief glance at their relevance to the immune system. Life Sci., 146, 163-173 (2016). https://doi.org/10.1016/j.lfs.2016.01.014

Bandoni, A. L., Los recursos vegetales aromáticos en Latinoamérica. Argentina. Editorial Universidad Nacional de la Plata. 2nd Ed., Buenos Aiers (2003).

Barroso, M. S. T., Villanueva, G., Lucas, A. M., Perez, G. P., Vargas, R. M. F., Brun, G. W., and Cassel, E., Supercritical fluid extraction of volatile and nonvolatile compounds from Schinusmolle L.BJChE, 28(2), 305-312 (2011). https://doi.org/10.1590/ S0104-66322011000200015

Brand-Williams, W., Cuvelier, M. E., and Berset, C. L. W. T., Use of a free radical method to evaluate antioxidant activity.LWT - Food Sci. Technol., 28(1), 25-30 (1995). https://doi.org/10.1016/ S0023-6438(95)80008-5

Cassel, E., Vargas, R. M. F., Brun, G. W., Almeida, D. E., Cogoi, L., Ferraro, G., and Filip, R., Supercritical fluid extraction of alkaloids from Ilex paraguariensis St. Hil. J. Food Eng., 100(4), 656-661 (2010). https://doi.org/10.1016/j. jfoodeng.2010.05.015

Castro-Vargas, H. I., Rodríguez-Varela, L. I., and Parada-Alfonso, F., Guava (Psidium guajava L.) seed oil obtained with a homemade supercritical fluid extraction system using supercritical $\mathrm{CO} 2$ and cosolvent. J. Supercrit. Fluids, 56(3), 238-242 (2011). https://doi.org/10.1016/j.supflu.2010.10.040

Castro-Vargas, H. I., Rodríguez-Varela, L. I., Ferreira, S. R., and Parada-Alfonso, F., Extraction of phenolic fraction from guava seeds (Psidium guajava L.) using supercritical carbon dioxide and co-solvents. J. Supercrit. Fluids, 51(3), 319-324 (2010). https:// doi.org/10.1016/j.supflu.2009.10.012

Cerpa, M. G., Mato, R. B., and José Cocero, M., Modeling steam distillation of essential oils: application to lavandin super oil. AIChEJ., 54(4), 909-917 (2008). https://doi.org/10.1002/aic.11438

Chen, H. Y., and Yen, G. C., Antioxidant activity and free radical-scavenging capacity of extracts from guava (Psidium guajava L.) leaves. Food Chem., 101(2), 686-694 (2007). https://doi.org/10.1016/j. foodchem.2006.02.047

Corrêa, L. C., Santos, C. A. F., Vianello, F., and Lima, G. P. P., Antioxidant content in guava (Psidium guajava) and araca (Psidium spp.) germplasm from different Brazilian regions. Plant Genetic Resources, 9(3), 384-391 (2011). https://doi. org/10.1017/S1479262111000025

Corti, R., Flammer, A. J., Hollenberg, N. K., and Lüscher, T. F., Cocoa and cardiovascular health. Circulation, 119(10), 1433-1441 (2009). https://doi. org/10.1161/CIRCULATIONAHA.108.827022
Croft, K. D., The chemistry and biological effects of flavonoids and phenolic acidsa.Annals of the New York Academy of Sciences, 854(1), 435-442 (1998). https://doi.org/10.1111/j.1749-6632.1998. tb09922.x

da Silva, E. A. J., da Silva, V. P., Alves, C. C. F., Alves, J. M., Souchie, E. L., and Barbosa, L. C. D. A., Harvest time on the content and chemical composition of essential oil from leaves of guava. Ciência Rural,46(10), 1771-1776 (2016). https:// doi.org/10.1590/0103-8478cr20150947

de Azevedo, A. B. A., Mazzafera, P., Mohamed, R. S., Melo, S. A. B., and Kieckbusch, T. G., Extraction of caffeine, chlorogenic acids and lipids from green coffee beans using supercritical carbon dioxide and co-solvents. Braz. J. Chem. Eng., 25(3), 543-552 (2008). https://doi.org/10.1590/S010466322008000300012

del Valle, J. M., and de La Fuente, J. C., Supercritical $\mathrm{CO}_{2}$ extraction of oilseeds: review of kinetic and equilibrium models. Crit. Rev. Food Sci. Nutr., 46(2), 131-160 (2006). https://doi. org $/ 10.1080 / 10408390500526514$

Díaz-de-Cerio, E., Gómez-Caravaca, A. M., Verardo, V., Fernández-Gutiérrez, A., and Segura-Carretero, A., Determination of guava (Psidium guajava L.) leaf phenolic compounds using HPLC-DADQTOF-MS.J. Funct. Foods, 22, 376-388 (2016). https://doi.org/10.1016/j.jff.2016.01.040

El-Ahmady, S. H., Ashour, M. L., and Wink, M., Chemical composition and anti-inflammatory activity of the essential oils of Psidium guajava fruits and leaves. J. Essent. Oil Res., 25(6), 475481 (2013). https://doi.org/10.1080/10412905.201 3.796498

Fernandes, M. R. V., Dias, A. L. T., Carvalho, R. R., Souza, C. R. F., and Oliveira, W. P., Antioxidant and antimicrobial activities of Psidium guajava L. spray dried extracts. Ind. Crops Prod., 60, 39-44 (2014). https://doi.org/10.1016/j.indcrop.2014.05.049

Flores, G., Wu, S. B., Negrin, A., and Kennelly, E. J., Chemical composition and antioxidant activity of seven cultivars of guava (Psidium guajava) fruits. Food Chem., 170, 327-335 (2015). https://doi. org/10.1016/j.foodchem.2014.08.076

Gutiérrez, R. M. P., Mitchell, S., and Solis, R. V., Psidium guajava: a review of its traditional uses, phytochemistry and pharmacology. J. Ethnopharmacol., 117(1), 1-27 (2008). https://doi. org/10.1016/j.jep.2008.01.025

Jayathilake, C., Rizliya, V., and Liyanage, R., Antioxidant and free radical scavenging capacity of extensively used medicinal plants in Sri Lanka. Procedia Food Sci., 6, 123-126 (2016). https://doi. org/10.1016/j.profoo.2016.02.028 
Johannsen, M. and Brunner, G., Solubilities of the xanthines caffeine, theophylline and theobromine in supercritical carbon dioxide. Fluid Phase Equilibria, 95, 215-226 (1994). https://doi. org/10.1016/0378-3812(94)80070-7

Khadhri, A., El Mokni, R., Almeida, C., Nogueira, J. M. F., and Araújo, M. E. M., Chemical composition of essential oil of Psidium guajava L. growing in Tunisia. Ind. Crops Prod., 52, 29-31 (2014). https:// doi.org/10.1016/j.indcrop.2013.10.018

Kumazawa, S., Yoneda, M., Shibata, I., Kanaeda, J., Hamasaka, T., and Nakayama, T., Direct evidence for the plant origin of Brazilian propolis by the observation of honeybee behavior and phytochemical analysis. Chem. Pharm. Bull., 51(6), 740-742 (2003). https://doi.org/10.1248/cpb.51.740

Laily, N., Kusumaningtyas, R. W., Sukarti, I., and Rini, M. R. D. K,. The Potency of Guava Psidium guajava (L.) Leaves as a Functional Immunostimulatory Ingredient. Procedia Chem., 14, 301-307 (2015). https://doi.org/10.1016/j.proche.2015.03.042

Lee, W. C., Mahmud, R., Pillai, S., Perumal, S., and Ismail, S., Antioxidant activities of essential oil of Psidium guajava L. leaves. APCBEE Procedia, 2, 86-91 (2012). https://doi.org/10.1016/j.apcbee.2012.06.016

Liu, J., Lin, S., Wang, Z., Wang, C., Wang, E., Zhang, Y., \& Liu, J. Supercritical fluid extraction of flavonoids from Maydis stigma and its nitritescavenging ability. Food Bioprod. Process., 89(4), 333-339 (2011). https://doi.org/10.1016/j. fbp.2010.08.004

Moura, P. M., Prado, G. H. C., Meireles, M. A. A., and Pereira, C. G., Supercritical fluid extraction from guava (Psidium guajava) leaves: Global yield, composition and kinetic data. J. Supercrit. Fluids, 62, 116-122 (2012). https://doi.org/10.1016/j. supflu.2011.11.014

Nantitanon, W., Yotsawimonwat, S., and Okonogi, S., Factors influencing antioxidant activities and total phenolic content of guava leaf extract.LWT - Food Sci. Technol., 43(7), 1095-1103 (2010). https://doi. org/10.1016/j.lwt.2010.02.015

Ogunwande, I.A., Olawore, N.O., Adeleke, K.A., Ekundayo, O. and Koenig, W., Chemical composition of the leaf volatile oil of Psidium guajava L. growing in Nigeria. Flav. Frag. J., 18, 136-138 (2003). https://doi.org/10.1002/ffj.1175

Pino, J.A., Aguero, J., Marbot, R. and Fuentes, V., Leaf Oil of Psidium gujava L. from Cuba. J. Essent. Oil Res., 13, 61-62 (2001). https://doi.org/10.1080/104 12905.2001.9699607

RENISUS. Relação Nacional de Plantas Medicinais de Interesse ao SUS. http://portal.saude.gov.br/ portal/arquivos/pdf/RENISUS.pdf. Accessed in 24 $\mathrm{abr} / 2016$ (2009).
Reverchon, E., Mathematical modeling of supercritical extraction of sage oil.AIChE J., 42(6), 1765-1771 (1996). https://doi.org/10.1002/aic.690420627

Rufino, M.D.S.M., Alves, R.E., Brito, E.S. de, Morais, S.M. de, Sampaio, C.D.G., Pérez-jiménez, J. and Saura-Colixto, F.D., Metodologia Científica: Determinação da Atividade Antioxidante Total em Frutas pela Captura do Radical Livre. Embrapa Agroindústria Tropical, 127, 4 (2007).

Qian, H., and Nihorimbere, V., Antioxidant power of phytochemicals from Psidium guajava. J. Zhejiang Univ. Sci., 5, 676-683 (2004). https://doi. org/10.1631/jzus.2004.0676

Sagrero-Nieves, L., Bartley, J.P. and Provis-Schwede, A., Supercritical fluid extraction of volatile components from the leaves of Psidium guajava $\mathrm{L}$. (Guava). Flav. Frag. J., 9, 135-137 (1994). https:// doi.org/10.1002/ffj.2730090309

Scopel, R., da Silva, C. F., Lucas, A. M., Garcez, J. J., do Espirito Santo, A. T., Almeida, R. N., and Vargas, R. M., Fluid phase equilibria and mass transfer studies applied to supercritical fluid extraction of Illicium verum volatile oil. Fluid Phase Equilib., 417, 203-211 (2016). https://doi.org/10.1016/j. fluid.2016.02.042

Soliman, F. M., Fathy, M. M., Salama, M. M., and Saber, F. R., Comparative study of the volatile oil content and antimicrobial activity of Psidium guajava L. and Psidium cattleianum Sabine leaves. Bull. Fac. Pharm. (Cairo Univ.), 54(2), 219-225 (2016). https://doi.org/10.1016/j.bfopcu.2016.06.003

Sovová, H., Mathematical model for supercritical fluid extraction of natural products and extraction curve evaluation. J. Supercrit. Fluids, 33(1), 35-52 (2005). https://doi.org/10.1016/j.supflu.2004.03.005

Sovová, H., Rate of the vegetable oil extraction with supercritical $\mathrm{CO}_{2}$ - I. Modeling of extraction curves. Chem. Eng. Science, 49, 409-414 (1994). https:// doi.org/10.1016/0009-2509(94)87012-8

Sovová, H., and Stateva, R. P., Supercritical fluid extraction from vegetable materials. Rev. Chem. Eng., 27(3-4), 79-156 (2011). https://doi. org/10.1515/REVCE.2011.002

Xavier, V. B., Vargas, R. M. F., Cassel, E., Lucas, A. M., Santos, M. A., Mondin, C. A., and Sartor, T., Mathematical modeling for extraction of essential oil from Baccharis spp. by steam distillation. Ind. Crops Prod., 33(3), 599-604 (2011). https://doi. org/10.1016/j.indcrop.2010.12.019

Zheng, W., and Wang, S. Y., Antioxidant activity and phenolic compounds in selected herbs. J. Agric. Food Chem., 49(11), 5165-5170 (2001). https:// doi.org/10.1021/jf010697n 